\title{
Social Context Factors and Attitudes toward Interracial Relationships on a South African University Campus
}

\author{
Acheampong Yaw Amoateng ${ }^{1}$ and Ishmael Kalule-Sabiti ${ }^{2}$ \\ ${ }^{1}$ Faculty of Human and Social Sciences, North West University, \\ Email: yaw.amoateng@nwu.ac.za \\ ${ }^{2}$ Population Training and Research Unit, Faculty of Human and Social Sciences, North West \\ University (Mafikeng Campus)
}

\begin{abstract}
The present study used a stratified random sample of undergraduate students at a major Metropolitan University in the Gauteng province of South Africa to examine aspects of the contact hypothesis as originally formulated by Gordon Allport. Specifically, the study sought to examine the effects of two social settings, namely, educational and religious settings on students' attitudes toward interracial relationships. We failed to find empirical support for our hypotheses that the higher education and religious settings would engender favourable attitudes towards interracial relationships. Rather we found the secondary education setting, being African, having intimate interactions with people of different racial backgrounds positively influence students attitudes towards interracial relationships.
\end{abstract}

Keywords: Contact Hypothesis; Inter-Racial dating; Education; Religion; Youth Identity

\section{Résumé}

La présente étude a employé un échantillon aléatoire stratifié d'étudiants d'étudiant préparant une licence à l'université de Johannesburg pour examiner des aspects de l'hypothèse de contact comme à l'origine formulé par Gordon Allport. Spécifiquement, l'étude a cherché à évaluer les effets de deux arrangements éducatifs et religieux sociaux d'arrangements, à savoir, attitudes sur étudiants des' envers dater interracial. Nous avons trouvé cela conformé à l'hypothèse de contact, le contact social entre les personnes de différents milieux sociaux tels que la course est crucial en favorisant des attitudes positives envers une des autres et que ces contacts sociaux sont en grande partie engendrés par des arrangements sociaux de contexte tels que le système d'éducation.

Mots-clés: clés entrent en contact avec l'hypothèse; datant; éducation; religion; jeunesse; identité

\section{Introduction}

South Africa is a country in transition from a past which was fractured along race, cultural and economic lines to a dispensation that is democratic and accepting of diversity. Like most countries undergoing such a transition, the society has placed enormous hopes on its youth who are in the majority demographically. According to the latest census figures, some 21 million or $41 \%$ of the country's population are children under the age of 20 years, while some 34 million or $68 \%$ of the population are under the age of 35 years (Statistics South Africa, 20II). The youth thus bridge the old and new generations of South Africans, provide an index of future social change and are a beacon of hope for the society.

In South Africa, it is a truism that past apartheid-induced legislation has vitiated the benefits that otherwise would have accrued to a racially and ethnically diverse population, a situation that has led to strenuous efforts on the part of political leaders to promote racial harmony since the political transition in 1994. In countries such as the United States, where there is a long tradition of research on interracial relationships, some of the early research focused on such relationships as a proxy for understanding race relations and acceptance of other groups (see e.g. Gordon, 1964). 
The purpose of the present study is to employ the Contact Hypothesis as originally proposed by Allport (1954), to examine students' attitudes towards interracial dating. We specifically examine two main social settings or contexts within which contact occurs: Educational and Religious settings. We contend that these two contexts either hinder or encourage acceptance of other groups and thus affect the positions people adopt on interracial dating. Besides these two settings, we also control for such factors as race and ethnicity, social class, gender, age, multiracial friendship, attitudes towards intimate and non-intimate interactions and racial composition of neighbourhoods.

\section{The Social Contact Hypothesis: A Theoretical Framework}

The essence of the Social Contact Hypothesis is that contact between groups is ameliorative and critical in improving intergroup relationships and that under specific conditions contact with members of different racial groups can promote positive and tolerant attitudes toward other groups (Allport, 1954, 1979; Pettigrew, 1998). It contends that the more contacts people have with others of different race, ethnicity and culture, the more tolerant they become to the different groups. In its classic formulation, the social contact hypothesis posits that positive outcomes to social contact occur only (I) in cooperative events, (2) among participants of equal status, (3) between those who hold common goals, and (4) with those who have supportive authority (see e.g. Aronson, Fried, and Good, 2002; Desforges et al., 1997; Powers and Ellison, 1995).

In the United States, some studies have employed the contact hypothesis to answer the question of contact and attitudes. These studies have generally found that those who have more interracial contact have more positive attitudes than those who do not and therefore tend to intermarry more. For example, Emerson, Kimbro and Yancey (2002) used this framework to study the effect of prior experiences of interracial contact in schools and neighborhoods on the likelihood of adults having more racially diverse general social groups and friendship circles. They found that 13 percent of married respondents who had both racially mixed experiences were interracially married compared to just 2.5 percent of those who had no racially mixed experience.

As already indicated, in this study, we focus on contact that occurs in educational and religious settings. As Johnson and Jacobson (2005) have noted, each of these settings provides opportunity for contact. However, there is variation in the degree of intimacy in the type of contact. Educational institutions invariably provide opportunities for increased intergroup contact and acceptance that may not exist elsewhere in society Johnson and Jacobson, 2005). Participation in higher education by the youth in transitional societies like South Africa exposes them to the opportunities provided by inclusive strategies which distil the divisive ills of the past and create a new diverse and unified nation. Moreover, this participation renders them creative and reflexive in the construction of knowledge as future elite of these societies. Besides these expectations of youth within the context of higher education institutions, the sweeping social, economic and political changes taking place at the broader societal and individual levels also impact students with regards to the constitution and reconstitution of their identities.

As far as the effect of education is concerned, in the United States, consistent with the view that Americans with higher levels of education are more racially progressive (see e.g. Farley, Steeh, Kryson, Jackson and Reeves, 1994), Wilson and Jacobson (1995) found that education was positively correlated with acceptance of racial exogamy, while Solsberry (1994) found that the majority of interracial romantic relationships were found among college students. Kamijn (1993) observed that approval of interracial marriage is the highest among college educated, while actual intermarriage rate is also higher among those who are college educated. In Sweden Törngren (20II) found that respondents who reported having completed above secondary education have around 1.5 to 2.5 times higher odds of reporting that they can imagine marrying a person of another origin. However, Ross (1994) in a study of college students' perceptions about interracial relationships did not find any significant relationship between the level of education and perceptions about interracial relationships. To assess the impact of educational setting on 
attitudes toward interracial dating, we examine the length of exposure to the higher education system by the respondent, parental education and the racial composition of the high school attended by the respondent.

Religious institutions are known to provide opportunities for both intergroup contact and injunctions about acceptance Johnson and Jacobson, 2005). In general, research from the U.S. indicates that people who are religious for intrinsic reasons (they get the message of all religions to love others) are less prejudiced and therefore less likely to oppose intergroup marriage. But those who go to church for extrinsic reasons (for social reasons only, to be part of the community, but don't get the message of religion) are more prejudiced, and therefore more likely to oppose intergroup marriage (see e.g. Batson, Schoenrade and Ventis, 1993; Hunsberger, 1995).

In their study, Johnson and Jacobson (1995), after controlling for the effects of other variables, found that each categorical increase in church attendance was associated with a 14 percent decrease in the odds of interracial marriage. However, the odds of approval among those who attended with a few blacks were about 50 percent higher than those who attended allwhite congregations. We examine the impact of religiosity on attitudes toward interracial dating and expect it to be positively associated with student attitudes toward interracial dating.

Contact also occurs in residential neighbourhoods. For example, Yancey (1999) has observed that neighbourhoods exhibit egalitarian relationships since in most cases they consist of individuals with similar socioeconomic backgrounds. Sigelman and Welch (1993) found that whites' contacts with blacks in their neighbourhood served as a source of information about blacks, while other residential studies have noted that whites who live in integrated housing projects develop favourable attitudes toward blacks at a faster rate than those who live in segregated projects (e.g. Pettigrew, 1998; Powers and Ellison, 1995; Yancey, 1999). However, Johnson and Jacobson (1995) did not find any significant relationship between residential composition and attitudes towards interracial marriage in their study.
In terms of race, studies in the United States have found significant differences between whites and African-Americans in terms of their perceptions of interracial relationships. These studies have found that on the whole AfricanAmericans are more accepting of such relationships than their white counterparts (see e.g. Knox, Zusman, Buffington \& Hemphill, 2000; Lee, Campbell \& Miller, 1991; Mills, Daly, Longmore \& Kilbride, 1995). Ross (2004) found that African-American college students have a more favourable perception of interracial relationships than their white counterparts regardless of gender. Moreover, South (1991) reports that blacks and Hispanics are more willing to marry someone of another race than whites are.

In a study of students at a university in Southern United States, Knox, Zusman, Buffington and Hemphill (2000) found that blacks were twice as likely as whites ( $83 \%$ vs. $43 \%$ ) to report that they were open to involvement in an interracial relationship, while blacks were almost three times as likely as whites to become seriously involved or to marry a person of another race; forty-nine percent of whites expressed mixed feelings and discomfort toward interracial dating and marriage (McClelland and Auster (1990). Moreover, Donscheski-Swinney (1999) found that white students viewed compatibility significantly more negatively for interracial couples than for other groups. In the present study, we expect black Africans and coloureds to have more positive attitudes toward interracial dating than their white and Indian counterparts.

As far as gender goes, Mills, Daly, Longmore and Kilbridge (1995) found that both men and women hold negative attitudes towards interracial relationships, but that women are significantly less accepting of interracial romantic relationships than men are. This finding corroborates that of Todd, Mckinney, Harris, Chadderton and Small (1992) in which they found that men showed significantly more positive attitudes toward interracial dating than did women. However, in an experimental study which sought to determine dating preferences amongst graduate students on a university campus in the U.S., Fisman, lyengar, Kamenica\& Simonson (2008) found that racial preferences 
were virtually identical for males and females. In Sweden, Törngren (20II) observed that men have conclusively higher odds of answering to the statement on interracial dating and marriage positively towards Adopted East Asians, Central/East European, Latin American, Middle Easterner and South/East Asian. In the U.S., even though Knox et al. (2000) found that almost half $(49.6 \%)$ of the respondents reported being open to involvement in an interracial relationship, they did not find any significant differences in sex between those who were open to this relationship and those who were not. Given the inconclusive evidence of gender differences with regards to attitudes towards interracial dating, in the present study we do not expect to find any differences between males and females.

Age is an important variable in relation to attitudes in general since as people age they tend to conform more to societal norms (e.g. Joyner and Kao, 2005; Todd, Mckinney, Harris, Chadderton and Small, 1992). Todd et al. (1992) investigated attitudes toward interracial dating in an ethnic-diverse community in the United States and found $61 \%$ of the participants were willing to date outside their ethnic group but most importantly, younger participants under the age of 40 , were significantly more positive about interracial dating than were older participants over age 40. Joyner and Kao (2005) found that interracial relationships are more common among the younger population in the U.S.

According to a USA Today/Gallup (1997) Survey of I,360 U.S. adults, 86 percent people aged 18 to 29 approved of marriage between blacks and whites compared to just 30 percent of those aged 65 and older who approved of such marriages. A study in Sweden on attitudes towards interracial dating and marriage found that those aged 45 and above have higher odds of responding negatively to the statement on interracial dating and marriage compared to respondents of the younger age category (Törngren, 20II). In the present study, we hypothesize that younger students will show positive attitudes toward interracial dating than their older counterparts

In recent years scholars of intergroup theories (e.g. Hogg \& Abrams, 200I) have expanded their work beyond conflicts across cultural groups by exploring interpersonal contexts of intergroup relations such as friendship (see e.g. Levin, van Laar, \& Sidanius, 2003) and intimate relationships (e.g., Fang, Sidanius, \& Pratto, 1998) that cut across cultural groups. Friendship provides an opportunity for people from different racial and cultural backgrounds to have contact with each other. Thus, friendship is a critical factor that affects interracial attitudes, motives, and most likely, approval of interracial dating (Johnson and Jacobson, 1995; Pettigrew, 1997; Powers and Ellison, 1995). Johnson and Jacobson (1995) found that friendship or interracial socializing was related significantly to approval of interracial marriage; specifically, a one-unit increase in the friendship scale was associated with a 34 percent increase in the odds of approving of interracial marriage. We expect interracial friendship and interracial socializing to positively affect attitudes toward interracial dating in the present study.

\section{Rationale}

As the above review of the literature on attitudes toward interracial dating has clearly shown, even though South Africa and the United States have a similar history of race relations, especially, in terms of the role of legislation banning interracial relationships, the empirical literature on the subject is predominantly American. In South Africa, it was not until ten years after the political transition that the first major empirical study looking at interracial marriages in the country was undertaken (see e.g. Jacobson, Amoateng, and Heaton, 2004).

This paucity of data on attitudes toward interracial relationships in South Africa could be due to the fact that the changes in legislation in South Africa are more recent compared to the United States. But while the longer history of interracial relationships in the United States justifies the predominance of the empirical literature in that context, the recent experience of South Africa also means that attitudes towards interracial relationships might not have changed a great deal. It is within this context and the massive changes that have taken place in the society both at the structural and individual levels since the political transition some two decades ago that more systematic studies of interracial relationships should be undertaken in South Africa.

Indeed empirical data are needed on the nature and dynamics of the identities within social 
relationships that young people form during their time as university students, and on the ways their diverse social backgrounds shape these relationships and their emerging identities. Moreover, data are needed on how and why young people creatively respond to these social backgrounds in creating their own identities and how national and global socio-economic and political changes impact these relationships and identities. Finally empirical evidence is sorely needed to answer the question as to how variations in attitudes towards interracial relationships among the student communities are shaped by social class, race, ethnicity, gender, and other relevant social contextual factors.

\section{Methods}

Data for the present study come from the quantitative component of the Student Communities' Project at a major public university in the Gauteng Province of South Africa. The survey, which was conducted in $201 \mathrm{I}$ amongst the university's undergraduate students on all four campuses, employed a random sample stratified by race, gender, campus and faculty. Specifically, using the Probability Proportional to Size (PPS) sampling scheme, the universe was divided into strata according to campus, faculty, race, gender and year of study.

Once the size of a sub-sample of a stratum had been established, the interviewers were instructed to purposively interview those numbers of students according to their 'quota' in terms of the stratification variables. Using this method, trained postgraduate students conducted structured interviews with 1214 students questioning them on a variety of issues related to their experiences as university students. For the purposes of this paper, students were asked about their attitudes toward interracial dating, their attitudes toward interactions with members of different racial groups on campus, multiracial friendships etc. We used SPSS version 20.0 for the analyses of the data.

\section{Measures of variables in the analysis}

\section{Dependent variable}

Two related items (a) "It is okay for people from different racial groups to date each other" and (b) People should feel free to marry whoever they want to marry regardless of their race", are used as our measure of "Attitudes Towards Interracial Relationships". These two items are measured on a five-point Likert scale which range from I "Strongly disagree....to 5 "Strongly agree". Factor analysis revealed that the two items were highly related and loaded on a single factor with an eigenvalue of 1.705 and explaining $85.27 \%$ of the variance (Cronbach's Alpha $=.827)$. Following this we computed the "Attitudes towards Interracial Relationships" Scale by computing the mean score of the two items'.

\section{Independent variables}

Religiosity: This was computed by the mean score of three items: To what extent does each of the following apply to you? (a) I consider myself a religious person (b) I participate in religious activities with others (c) I practice religious activities privately. Measured on a fivepoint Likert scale, the responses to the two items ranged from I"Strongly Disagree....to....5 "Strongly Agree.

Educational setting: Two variables were used to assess the impact of educational settings on students' attitudes towards interracial dating. First, a new variable which measured length of exposure to the higher education setting was derived from subtracting year of first registration from the survey year (20ll). The second variable which was used to assess the impact of educational setting was the racial composition of the high school attended by the students. It was measured by the question: "Which of the following describe best the high school you attended"? And the responses were: mainly black, mainly white, mainly coloured, mainly Indian/Asian,

mixed black/white/coloured/Indian/Asian. This was recoded into three high school types: (I) African Segregated (2) Non-African Segregated and (3) Mixed.

Multiracial friendship: Multiracial friendship was computed by the mean score of two items which measured the extent to which respondents socialize with people from another racial group and the extent to which they have friends who are members of a different racial group. This was

\footnotetext{
${ }^{1}$ See Table 1 for the measurement of the scales.
} 
a five-point scale ranging from I "To no extent....to...5 "To a very large extent".

Non-intimate interaction: Non-intimate interaction was computed by the mean score of four items which measured the extent to which respondents were comfortable attending lectures, participating in a study group, sharing accommodation but not in the same room and being friends with somebody of a different race than their own. The responses ranged from I "To no extent....to...5 "To a very large extent".

Intimate interaction: Intimate or close interaction was computed by the mean score of two items which measured the extent to which respondents felt comfortable sharing a room and dating somebody of a different race than their own. The responses ranged from I "To no extent....to...5 "To a very large extent".

Social class: The student's social class was measured by mother's educational attainment. The question used to measure mother's education was: "What is your mother's/guardians' highest level of education"? This was measured at the ordinal level and the responses ranged from I "None, no education" to 7 "Postgraduate degree".

Racial Composition of Neighbourhood: This was measured by the question: "Which one of the following categories best describes the people in the neighbourhood where you live (your home) during the university holidays."? The responses were: mainly black people, mainly white people, mainly coloured people, mainly Indian/Asian people, mixed black/white/coloured/Indian/Asian people. This was recoded into three types of neighbourhood: (I) Mainly African (2) Mainly non-African (3) Mixed

Race: Race is dummied with Africancoded as I and Non-African (White/Indian/Asian, coloured) coded as $=0$.

Gender: is measured as a dummy variable coded as Male $=I$ and Female $=0$.

Residence: Rural/Urban residence was measured by a question which asked students about the location of the High School they attended. The response categories were as follows: I= Government school in urban area (suburb) 2= Government school in urban area (township) $3=$ Government school in rural area (town) $4=$ Government school in rural area (township)
$5=$ Home schooling $6=$ Private school and $7=$ Other. These were recoded into four (4) main categories, namely, I=Urban (Suburb) $2=$ Urban (Township) $3=$ Rural $4=$ Other (private/other).

Table I: Descriptive Statistics of Scales and Items

Variable and Items

\begin{tabular}{|c|c|c|c|c|}
\hline & $\mathbf{N}$ & Mean & Median & Std.Dev. \\
\hline $\begin{array}{l}\text { Interrracial } \\
\text { Relationship }\end{array}$ & 1210 & 4.230 & 4.500 & 0.920 \\
\hline $\begin{array}{l}\text { It is okay for } \\
\text { people from } \\
\text { different racial } \\
\text { groups to date } \\
\text { each other. }\end{array}$ & & & & \\
\hline $\begin{array}{l}\text { People should } \\
\text { be free to } \\
\text { marry whoever } \\
\text { they want to } \\
\text { marry } \\
\text { regardless of } \\
\text { their race }\end{array}$ & & & & \\
\hline Religiosity & 1202 & 3.550 & 3.667 & 0.948 \\
\hline $\begin{array}{c}\text { I consider } \\
\text { myself a } \\
\text { religious person }\end{array}$ & & & & \\
\hline $\begin{array}{l}\text { I participate in } \\
\text { religious } \\
\text { activities with } \\
\text { others }\end{array}$ & & & & \\
\hline $\begin{array}{l}\text { I practise } \\
\text { religious } \\
\text { activities } \\
\text { privately }\end{array}$ & & & & \\
\hline $\begin{array}{l}\text { Multiracial } \\
\text { Friendship }\end{array}$ & 1207 & 3.341 & 3.500 & 1.019 \\
\hline $\begin{array}{l}\text { I socialise with } \\
\text { people from } \\
\text { another racial } \\
\text { group }\end{array}$ & & & & \\
\hline $\begin{array}{l}\text { I have friends } \\
\text { who are } \\
\text { members of a } \\
\text { different racial } \\
\text { group }\end{array}$ & & & & \\
\hline $\begin{array}{l}\text { Non-Intimate } \\
\text { Interaction }\end{array}$ & 1205 & 3.717 & 3.750 & 0.874 \\
\hline
\end{tabular}




\begin{tabular}{|c|l|l|l|l|}
\hline $\begin{array}{c}\text { Attending } \\
\text { lectures }\end{array}$ & & & & \\
\hline $\begin{array}{c}\text { Participating in } \\
\text { a study group }\end{array}$ & & & & \\
\hline $\begin{array}{c}\text { Sharing } \\
\text { accommodation } \\
\text { but not the } \\
\text { same room }\end{array}$ & & & & \\
\hline $\begin{array}{c}\text { Being friends } \\
\text { Intimate } \\
\text { Interaction }\end{array}$ & 1209 & 3.108 & 3.000 & 1.177 \\
\hline $\begin{array}{c}\text { Sharing a room } \\
\text { with somebody } \\
\text { of a different } \\
\text { race }\end{array}$ & & & & \\
\hline $\begin{array}{c}\text { Dating } \\
\text { somebody of a } \\
\text { different race }\end{array}$ & & & & \\
\hline
\end{tabular}

\section{Statistical Analytical Approach}

The analysis proceeds on two main levels, namely, bivariate and multivariate. For the descriptive statistics, we use such descriptive statistical techniques as frequencies, means, mode and standard deviation to provide a description of the distribution of all the variables in the analysis one at a time. For the multivariate or inferential statistical analysis to test the study's central hypotheses, it is worthy of note that the dependent variable, "Attitudes towards Interracial Relationships", is measured by the mean of two items measured on a 5-point Likert scale. Moreover, most of the predictor variables are measured on similar Likert scales (Multiracial friendship, Religiosity, Non-intimate and Intimate interactions). The fact that some of the variables are measured at the ordinal level therefore suggests the use of the Wilcoxon Rank Sum Tests as the preferred statistical technique to test the study's central hypotheses (e.g. Lowry 201 I; Wilcoxon 1945).

As an exploratory measure, we used a Parametric Analysis of Covariance. Since the assumption of normality of the residuals was violated, we do not report those results. Rather, we used a nonparametric approach to examine the effect of multiple factors. Specifically, Cochran-MantelHaenszel methodology was used wherein the primary factor of interest was examined while stratifying on secondary factors (e.g. the factor of African Race was examined while stratifying on Racial Composition of High School attended and Intimate interactions). We made an a priori decision, based on theory, that a mean difference of at least .50 on Interracial Relationship Scale would be needed to be of practical significance.

In the use of the Wilcoxon Rank Tests, we made a priori decision, based on theory, that a mean difference of .50 at the $.05 \%$ threshold of significance will be acceptable ${ }^{2}$. The test makes three crucial assumptions about the data. Firstly, it assumes that the data are paired and come from the same population. Secondly, it assumes that each pair is chosen randomly and independently, and finally, it assumes that the data are measured at least on an ordinal scale, but need not be normal

\section{Results}

\section{Sample Characteristics}

Table 2 shows the description of the sample characteristics. The mean age of the respondents was 21 years and the average length they had been exposed to higher education at the time of the survey was I. 18 years. Males constituted $47 \%$ of the sample compared to $53 \%$ of females. The vast majority of the respondents were black Africans who constituted $80.1 \%$ of the total sample, while non-Africans constituted only $20 \%$ of the total. In terms of religious affiliation, $83 \%$ of the respondents were Christian compared to only $17 \%$ non-Christians. Fifty-five percent of the respondents reported attending high schools that composed of mainly Africans $18 \%$ attended mainly non-African high schools, while $28 \%$ attended high schools that were racially mixed. As far as the racial composition of neighbourhood was concerned, $61 \%$ reported that they lived in mainly African neighbourhoods, $20 \%$ lived in mainly non-African neighbourhoods, while $19 \%$ lived in mixed residential neighbourhoods. Finally, in terms of maternal educational attainment, $27 \%$ of the respondents' mother had Matric education, $18 \%$ had postgraduate education, while only $4 \%$ had no schooling at all.

\footnotetext{
${ }^{2}$ This is in recognition of the fact that with a sample size of over a 1,000 cases, statistical significance would not be difficult to attain so the question becomes if a mean difference of at least .50 is of "practical" rather than "statistical" importance?
} 
Table 2: Distribution of Sample Characteristics Variable

\begin{tabular}{|c|c|c|}
\hline & $\mathbf{N}$ & $\%$ \\
\hline \multicolumn{3}{|l|}{ Gender } \\
\hline $\begin{array}{l}\text { Male } \\
\text { Female }\end{array}$ & $\begin{array}{l}569 \\
645 \\
\end{array}$ & $\begin{array}{l}46.9 \\
53.1\end{array}$ \\
\hline \multicolumn{3}{|l|}{ Race } \\
\hline $\begin{array}{l}\text { African } \\
\text { Non-African }\end{array}$ & $\begin{array}{l}973 \\
241 \\
\end{array}$ & $\begin{array}{l}80.1 \\
19.9 \\
\end{array}$ \\
\hline \multicolumn{3}{|l|}{ Religious Affiliation } \\
\hline $\begin{array}{l}\text { Christian } \\
\text { Non-Christian }\end{array}$ & $\begin{array}{l}1010 \\
204\end{array}$ & $\begin{array}{l}83.2 \\
16.8 \\
\end{array}$ \\
\hline \multicolumn{3}{|c|}{ Racial Composition of } \\
\hline $\begin{array}{l}\text { Mainly African } \\
\text { Mainly Non-African } \\
\text { Mixed }\end{array}$ & $\begin{array}{l}664 \\
213 \\
335\end{array}$ & $\begin{array}{l}54.7 \\
17.6 \\
27.6\end{array}$ \\
\hline \multicolumn{3}{|c|}{ Racial Composition of } \\
\hline $\begin{array}{l}\text { Mainly African } \\
\text { Mainly Non-African } \\
\text { Mixed }\end{array}$ & $\begin{array}{l}742 \\
245 \\
227\end{array}$ & $\begin{array}{l}61.1 \\
20.2 \\
18.7\end{array}$ \\
\hline \multicolumn{3}{|l|}{ Mother's Education } \\
\hline No schooling & 34 & 3.5 \\
\hline Primary & 41 & 4.2 \\
\hline Some secondary & 147 & 15.2 \\
\hline Matric & 258 & 26.6 \\
\hline College diploma & 177 & 18.2 \\
\hline Undergraduate degree & 142 & 14.6 \\
\hline Postgraduate degree & $17 \mid$ & 17.6 \\
\hline
\end{tabular}

Table 3 shows the results of the Wilcoxon Rank Sum Tests of the relationship between selected predictor variables and attitudes towards interracial relationships. The overall attitude of students towards interracial relationship is positive as more than three-quarters $(76.3 \%)$ of the respondents approved of interracial dating as compared to less than a quarter (23.5\%) who disapproved of interracial dating. Africans are much more likely than non-Africans to have favourable attitudes towards interracial relationships While female students are more likely than their male counterparts to have more favourable attitudes towards interracial relationships, the difference is not big enough to meet our criterion of 'practical' importance. The same observation is made of both maternal education and residence; neither of them makes any difference with regards to attitudes towards interracial relationships.

The favourable attitudes of Africans towards interracial relationships is further illustrated by the finding that students who attended high schools dominated by Africans and those who live in neighbourhoods dominated by Africans are much more likely than high schools and neighbourhoods dominated by other race groups to have favourable attitudes towards interracial relationships. Also, attending high schools and living in neighbourhoods that are racially mixed engenders positive attitudes towards interracial relationships. Christians are more likely to have more favourable attitudes towards interracial relationships although $(p=0.0037)$, the difference is hardly big enough to be of practical importance 
Table 3: Descriptive Statistics of Rank Sum Tests* Results

\begin{tabular}{|c|c|c|c|c|}
\hline Variable & $\mathbf{N}$ & Mean & Std. Dev. & p-value \\
\hline Race & & & & $<.0001$ \\
\hline \multirow{3}{*}{$\begin{array}{l}\text { African } \\
\text { Non-African }\end{array}$} & 973 & 4.36 & 0.821 & \\
\hline & & & & \\
\hline & $24 I$ & 3.71 & 1.099 & \\
\hline \multirow{3}{*}{$\begin{array}{l}\text { Gender } \\
\text { Male } \\
\text { Female }\end{array}$} & & & & $<.0001$ \\
\hline & 568 & 4.12 & 0.956 & \\
\hline & 642 & 4.33 & 0.877 & \\
\hline \multirow{5}{*}{$\begin{array}{l}\text { Residence } \\
\text { Urban (Suburb) } \\
\text { Urban (Township) } \\
\text { Rural } \\
\text { Other (Private/Home) Schooling }\end{array}$} & & & & 0.1391 \\
\hline & 456 & 4.20 & 0.942 & \\
\hline & 288 & 4.34 & 0.834 & \\
\hline & 218 & 4.11 & 1.033 & \\
\hline & 246 & 4.25 & 0.857 & \\
\hline \multirow{4}{*}{$\begin{array}{l}\text { Maternal Educati } \\
\text { None/Primary } \\
\text { Some Sec/Matric } \\
\text { College }^{+}\end{array}$} & & & & 0.0234 \\
\hline & 221 & 4.31 & 0.879 & \\
\hline & 257 & 4.14 & 0.927 & \\
\hline & 490 & 4.29 & 0.895 & \\
\hline \multirow{3}{*}{$\begin{array}{l}\text { Racial Composition of High School } \\
\text { Attended } \\
\text { Mainly African }\end{array}$} & & & & $<.0001$ \\
\hline & 661 & 4.30 & 0.862 & \\
\hline & 212 & 3.78 & 1.139 & \\
\hline \multicolumn{5}{|l|}{ Mainly Non-African } \\
\hline Mixed & 335 & 4.38 & 0.781 & \\
\hline Racial Composition of Neighbourhood & & & & $<.0001$ \\
\hline Mainly African & 739 & 4.32 & 0.860 & \\
\hline \multirow[t]{2}{*}{ Mainly Non-African } & 244 & 3.87 & 1.113 & \\
\hline & 227 & 4.33 & 0.772 & \\
\hline \multirow[t]{2}{*}{ Religious Affiliation } & & & & 0.0037 \\
\hline & 1007 & 4.27 & 0.884 & \\
\hline Non-Christian & 203 & 4.03 & 1.060 & \\
\hline
\end{tabular}

${ }^{*}$ Kruskal-Walis Tests when variable has more than two categories/Wilcoxon Tests when variable has only two categories.

\section{Multivariate Analysis}

Table 4 shows the results of Spearman Correlation Coefficients for the relationships between the predictor scales and attitudes towards interracial 631 relationships. As table shows, intimate interaction scores are correlated with the Attitudes towards Interracial Relationships Scale. Since Intimate interaction and non-intimate interaction are highly 
correlated (0.65577), we chose to use to use only the Intimate Interaction and non-Intimate Interaction score for the multivariate analysis. Moreover, the racial composition of high school and neighborhood variables were strongly related so we chose to use only High School Composition variable for the multivariate analysis. In addition to being correlated with Attitudes towards Interracial Relationships variable, the Intimate Interaction scores are almost I point higher among African than non-African.

Therefore it is possible that differences attributed to African might be explained by intimate interaction. We therefore used this variable can be used as a covariate in an analysis of covariance (ancova). Using parametric ancova suggested that Racial Composition of High School, African, Intimate Interaction, and the interaction between the last two factors might be highly significant (calculated $\mathrm{p}<0.000 \mathrm{I}$ in each case). However, since the assumption of normally distributed residuals was violated, we chose to use nonparametric methods to further examine the effect of multiple factors. Specifically, Cochran-MantelHaenszel $(\mathrm{CMH})$ methodology was used wherein the primary factor of interest was examined while stratifying on secondary factors (e.g. the factor of African Race was examined while stratifying on Racial Composition of High School attended and Intimate interactions). The $\mathrm{CMH}$ analysis supported the ancova results in that each of the primary factors was significantly related to the "attitudes towards interracial relationships outcome variable after adjusting for the other two factors $(p<0.000 \mathrm{I}$ in all three

cases).

Table 4: Spearman's Correlations Coefficients

\begin{tabular}{|c|c|c|c|c|c|}
\hline & AIR $^{*}$ & Religiosity & $\begin{array}{l}\text { Multiracial } \\
\text { Friendship }\end{array}$ & $\begin{array}{l}\text { Non-Intimate } \\
\text { Interaction }\end{array}$ & $\begin{array}{c}\text { Intimate } \\
\text { Interaction }\end{array}$ \\
\hline $\begin{array}{c}\text { AIR } \\
\text { p-value } \\
\mathrm{N}\end{array}$ & $\begin{array}{c}1.00 \\
-- \\
1210\end{array}$ & $\begin{array}{c}0.01696 \\
0.5575 \\
1198\end{array}$ & $\begin{array}{c}0.13308 \\
<.0001 \\
1204\end{array}$ & $\begin{array}{c}0.31154 \\
<.0001 \\
1203\end{array}$ & $\begin{array}{c}0.39368 \\
<.000 \mid \\
1207\end{array}$ \\
\hline $\begin{array}{c}\text { Religiosity } \\
\text { P-value } \\
\text { N }\end{array}$ & $\begin{array}{c}0.01696 \\
0.5575 \\
1198\end{array}$ & $\begin{array}{c}1.00 \\
-- \\
1202\end{array}$ & $\begin{array}{c}0.06998 \\
0.0155 \\
1195\end{array}$ & $\begin{array}{c}0.04918 \\
0.0895 \\
1193\end{array}$ & $\begin{array}{c}-0.03846 \\
0.2924 \\
1197\end{array}$ \\
\hline $\begin{array}{c}\text { Multiracial } \\
\text { Friendship } \\
\text { P-value } \\
\mathrm{N}\end{array}$ & $\begin{array}{c}0.13308 \\
<.0001 \\
1204\end{array}$ & $\begin{array}{c}0.06998 \\
0.0155 \\
1195\end{array}$ & $\begin{array}{c}1.00 \\
-- \\
1207\end{array}$ & $\begin{array}{c}0.255122 \\
<.0001 \\
1199\end{array}$ & $\begin{array}{c}0.13315 \\
<.0001 \\
1203\end{array}$ \\
\hline $\begin{array}{c}\text { Non-intimate } \\
\text { interaction } \\
\text { P-value } \\
\mathrm{N}\end{array}$ & $\begin{array}{c}0.31154 \\
<.0001 \\
1209\end{array}$ & $\begin{array}{c}0.04918 \\
0.0895 \\
1193\end{array}$ & $\begin{array}{c}0.255122 \\
<.0001 \\
1199\end{array}$ & $\begin{array}{c}1.00 \\
-- \\
1205\end{array}$ & $\begin{array}{c}0.65577 \\
<.0001 \\
1205\end{array}$ \\
\hline $\begin{array}{c}\text { Intimate } \\
\text { interaction } \\
\text { P-value } \\
\mathrm{N}\end{array}$ & $\begin{array}{c}0.39368 \\
<.0001 \\
1207\end{array}$ & $\begin{array}{c}-0.03846 \\
0.2924 \\
1197\end{array}$ & $\begin{array}{c}0.13315 \\
<.0001 \\
1203\end{array}$ & $\begin{array}{c}0.65577 \\
<.0001 \\
1205\end{array}$ & $\begin{array}{c}1.00 \\
-- \\
1209\end{array}$ \\
\hline
\end{tabular}

"Attitude towards Interracial Relationships. 


\section{Conclusion and Discussion}

Several scholars have noted that even though they exhibit variation in the degree of intimacy in the type of contact they engender, these two settings provide opportunities for increased intergroup contact and acceptance that may not exist elsewhere in society. Since the 1994 political transition, the qualitative and quantitative changes that have taken place in the country's higher education sector have not only ensured greater participation in the sector by the country's youth, but through this medium, the youth have also been exposed to opportunities for creating new identities that are required for the envisioned non-racial society ${ }^{3}$.

It was within this context of the role of the higher education system in the creation of an environment that engenders the reconfiguration of youth identities that we undertook the present study. Measured by a student's length of exposure to the higher education system and to a large extent, maternal educational attainment, exposure to the higher education system did not have a significant association with students' attitudes towards interracial relationships. It was rather the racial composition of the high school attended by the student that was significantly related to attitudes towards interracial relationships in that students who reported that they attended a racially mixed high school had a more favourable attitudes towards interracial relationships and vice versa. Like exposure to the higher education setting, religious setting measured by religious affiliation and religiosity, was not significantly associated with attitudes towards interracial relationships.

But, being African and having intimate interaction with people of different racial backgrounds were significantly associated with favourable attitudes towards interracial relationships.

On the face of it, the study's findings would seem to suggest that the two social context settings, namely, educational and religious, do not influence attitudes towards interracial relationships. However, in our view such a conclusion would be hasty in the face of the other findings, especially, such contact-related factors as racial composition of high school attended and intimate interactions with people from other race groups. What these findings seem to suggest is that it is not necessarily the content of the education that the education system provides that makes a difference with regards to the acceptance of interracial relationships, but rather the opportunities the educational settings provides for the formation of

\footnotetext{
${ }^{3}$ We observed from this study that the pace of racial integration in the education sector by far outstrips that of other sectors, especially, residential neighbourhoods.
} 633 multiracial friendships and interactions with people from different racial, ethnic and class backgrounds.

This point about the role of the education system in identity formation and reconfiguration with regard to the youth is vividly illustrated by the significant association we found between racial composition of schools at the secondary level and attitudes towards interracial relationships. Moreover, this point about social contexts providing opportunities for contacts and friendships between people from diverse social backgrounds is further illustrated by the lack of association between our measure of religious 'setting'-religious affiliation and religiosity-and attitudes towards interracial relationships.

While religiosity may be an important dimension of religion which affects both attitudes and behaviours of individuals, the use of this dimension of religion to assess the effect of the contact hypothesis was misplaced and represents a limitation of the present study. Future research therefore would do well to include in the analysis of the effect of religious setting on intergroup relations a variable such as the racial composition of specific religious organisations like churches, mosques, synagogues etc.

In conclusion, the fact that the educational system as a whole performs the function of providing the opportunities for people from different racial backgrounds to meet and get to know each other better notwithstanding, the present study has shown that efforts at racial integration at the secondary school level are yielding more positive results than those at the higher education level.

\section{References}

Allport, G.W. (1954). The Religious Context of Prejudice. Journal for the Scientific Study of Religion, Vol. 5: 447-57.

Allport, Gordon W. (1979). The Nature of Prejudice.Unabridg, 25th anniversaryed. Reading, Mass.: Perseus books.

Aronson, J, Fried, C.B., and Good, C. (2002). Reducing the Effects of Stereotype Threat on African American College Students by Shaping Theories of Intelligence. Journal of Experimental Social Psychology, Vol. 38: 125-38.

Crowder, K.D.and Tolnay, S.E. (2000). A New Marriage Squeeze for Black Women: The Role of Racial Intermarriage by Black Men. Journal of Marriage and the Family, Vol. 62: 792-807.DeMaris A, (1995).Tutorial in Logistic Regression.Journal of Marriage and the Family, 57:956-968.

Desforges, D.M., Lord, C.G., Pugh, M.A., Sia, T.L., Scarberry, N.C., and Ratcliff, C.D. (1997). Role of Group Representativeness in the Generalization Part of the Contact Hypothesis.Basic and Applied Social Psychology, Vol. 19: 183-204. 
Donscheski-Swinney, A.D. (1999). Perceptions of couples' compatibility: Racial bias. Journal of Psychological Inquiry, Vol. 4: 30-32.

Emerson, Michael O., Rachel Tolbert Kimbro, and George Yancey. (2002). Contact Theory Extended: The Effects of Prior Racial Contact on Current Social Ties. Social Science Quarterly, Vol. 83 (3): 745-6I.

Fang, C. Y., Sidanius, J., \&Pratto, F. (1998). Romance across the social status continuum: Interracial marriage and the ideological asymmetry effect. Journal of Cross-Cultural Psychology, 29, 290-305.

Farley, R., Steeh, C., Kryson, M., Jackson, T. and Reeves, K. (1994). Stereotypes and Segregation: Neighborhoods in the Detroit Area. American Journal of Sociology, Vol. 100: 750-780.

Fisman, R., lyengar, S.S., Kamenica, E., \& Simonson, I. (2008). Racial Preferences in Dating. Review of Economic Studies, Vol. 75: I I7-132

Gordon, M.M. (1964). Assimilation in American Life. New York: Oxford University Press.

Harris, T.M. and Kalbfleisch, P.J. (2000). Interracial Dating: The Implications of Race for Initiating a Romantic Relationship. The Howard Journal of Communications, Vol. II: 49-64.

Heaton, T.B. and Albrecht, S.L. (199I). The changing Patterns of Interracial Marriage. Social Biology, Vol. 43(3-4): 203-2I7.

Hogg, M. A., \& Abrams, D. (Eds.).(200I). Intergroup relations. Philadelphia: Psychology Press.

Jacobson, C.K., Amoateng, A.Y. and Heaton, T.B. (2004). Inter-racial marriages in South Africa. Journal of Comparative Family Studies, Vol. 35: 443458.

Johnson, B. and Jacobson, C.K. (2005). Contact in Context: An Examination of Social Settings on Whites' Attitudes Toward Interracial Marriage. Social Psychology Quarterly, Vol. 68(4): 387-399.

Joyner, K. and Kao, G. (2005). Interracial Relationships and the Transition to Adulthood.American Sociological Review, Vol. 70.4 (2005): 563-58I.

Kalmijn, M. (1993).Trends in Black/White Intermarriage.Social Forces, Vol. 72: I I9-146.

Knox, D., Zusman, M.E., Buffington, C. \& Hemphill, G. (2000). Interracial dating attitudes among college students. College Student Journal, Vol. 34(I): 69-7I.

Kouri, K.M. and Lasswell, M. (1993). Black-White Marriages: Social change and intergenerational mobility. Marriage and Family Review, Vol. 19(3-4): 24I-255

Lee, B.A., Campbell, K.E., \& Miller, O. 9199I). Racial differences in urban neighbourhoods. Sociological Forum, Vol. 6: 525-550.
Levin, S., van Laar, C., \& Sidanius, J. (2003). The effects of ingroup and outgroup friendships on ethnic attitudes in college: A longitudinal study. Group Processes and Intergroup Relations, Vol. 6, 76-92.

Lewis, R. And Yancey, G. (1994). Biracial Marriage in the United States: An Analysis of Variance in Family Member. Support.Sociological Spectrum, Vol. I5: 443-462.

Lowry, R. (20II). Concepts \& Applications of Inferential Statistics. Retrieved 24 March 201 I.

McClelland, K.E. and Auster, C.J. (1990). Public attitudes and hidden tensions. Journal of Higher Education, Vol. 61:607-639.

Mills, J.K., Daly, J., Longmore, A., \& Kilbride, G. (1995). A note on family acceptance involving interracial friendships and romantic relationships. Psychological Reports, Vol. I(69): 753-754.

Nimubona, A., \&Vencatachellum, D. (2007). Intergenerational education mobility of black and white South Africans. Journal of Population Economics, 20, 149-182.

Pettigrew, T.F. (1998). Intergroup Contact Theory.Annual Review of Psychology, Vol. 49: 65-85.

Pettigrew, T.F. (1997). Generalized Intergroup Contact Effects on Prejudiced.Personality and Social Psychology Bulletin, Vol. 23: 173-85.

Powers, D.A. and Ellison, C.G. (1995). Interracial Contact and Black Racial Attitudes: The Contact Hypothesis and Selectivity Bias. Social Forces, Vol. 74: 205-26.

Ross, W. (2004). The Perceptions of College Students about Interracial Relationships.National Forum of Applied Educational Research Journal-Electronic, Vol. I7E(3), 2004-05.

Sigelman, L. And Welch, S. (1993). The Contact Hypothesis Revisited: Black-White Interaction and Positive Racial Attitudes. Social Forces, Vol. 7I: 78I-95.

Solsberry, P.W. (1994). Interracial couples in the United States of America: Implications for mental health counselling. Journal of Mental Health Counseling, Vol. 16(3): 304-3I7.

South, S. J. (199I). Sociodemographic Differentials in Mate Selection Preferences.Journal of Marriage and Family, Vol. 53: 928-940.

Statistics South Africa (20II), Mid-Year Population Estimates. Statistical Release P0302, ,Pretoria.

Tood, J., McKinney, J.L., Harris, R., Chadderton, R..\& Small, L. (1992).Attitudes toward interracial dating: Effects of age, sex, and race. Journal of Multicultural Counseling and Development, Vol. 20: 202-208.

Törngren, S.O. (20II). Attitudes towards interracial dating and marriages: Examination of the role of 
interracial contacts in Malmö, Sweden, WWW.bit.mah.se/MUEP.

Tucker, M.B. and Mitchell-Kernan, C. (1990). New Trends in Black American Interracial Marriage: The Social Structural Context. Journal of Marriage and the Family, Vol. 52: 209-2I8.

USA Today/Gallup Poll.(1997). Interracial Teen Dating. October 13-20.

Wilcoxon, F. (1945). Individual Comparisons by Ranking Methods. Biometrics Bulletin, I (6): 8083.

Wilson, D.S. and Jacobson, C.K. (1995). White Attitudes towards Black and White Interracial Marriage. Pp. 353-367 in Cardell K. Jacobson (ed.), American Families: Issues in Race and Ethnicity. New York: Garland Publications.
Yancey, G. and Yancey, S. (1998). Interracial Dating: Evidence from the Personal Advertisements. Journal of Family Issues, Vol. 19(3) 334-348.

Yancey, G. (1999). An Examination of the Effects of Residential and Church Integration on Racial Attitudes of Whites. Sociological Perspectives, Vol. 42: 279-304.

Yancey, G. And Yancey, S. (1997). Black-White Differences in the Use of Personal Advertisements for Individuals seeking Interracial Relationships. Journal of Black Studies, Vol. 27(5): 650-667.

\section{Authors' Contribution:}

Professor AY Amoateng was responsible for statistical analysis and write up of the data, while Professor Ishmael Kalule-Sabiti contributed to the bulk of the literature review. 